\title{
The ecology of Echinococcus multilocularis \\ Leuckart, 1863, (Cestoda : Taeniidae) on St. Lawrence Island, Alaska
}

\author{
I. Background and rationale
}

\author{
by F. H. FAY \\ Arctic Health Research Center, \\ U.S. Department of Health, Education, and Welfare, \\ Fairbanks, Alaska 99701, U.S.A.
}

\begin{abstract}
Summary
A 15-year study of the ecology and enzootiology of E. multilocularis on St. Lawrence Island, Bering Sea, is introduced by a resume of the physical and biotic conditions of the study area, brief reviews of the life cycle of the cestode and its natural hosts, and a few remarks on the epidemiology of alveolar hydatid disease on the island.

The island, about $5000 \mathrm{~km}^{2}$ in area, is mainly tundra, with a relatively cold, wet climate and depauperate fauna and flora. The principal hosts of E. multilocularis on the island are the arctic fox, Alopex lagopus, and the northern or root vole, Microtus aconomus, which inhabit most of the area and whose populations are cyclic, with a 3- to 4-year frequency. The study, begun in 1956, comprised a 4-year intensive phase, in which the host and parasite populations and the environment were examined in detail, and an 11-year follow-up phase, in which the results of the earlier work were repeatedly tested in the field and under laboratory conditions. Primary emphasis was placed on the influence of population cycles of the natural hosts on the abundance of the parasite. Comparative studies of the synanthropic life cycle, involving sledge dogs and voles in the island's largest Eskimo village, also were undertaken. Subsequent reports will present the findings.
\end{abstract}




\section{Résumé}

\section{Ecologie d'Echinococcus multilocularis Leuckart, 1963 (Cestoda : Taeniidae) dans l'île Saint-Laurent (Alaska).}

Cette étude, poursuivie pendant 15 ans sur l'écologie et l'enzootiologie d'Echinococcus multilocularis à l'Ile St-Laurent (mer de Bering), commence par une étude des états physiques et biotiques de l'atmosphère, par une revue brève des cycles évolutifs du Cestode et de ses hôtes naturels et par quelques explications sur l'épidémiologie de l'hydatidose alvéolaire dans l'île.

L'île, dont l'étendue est approximativement de $5000 \mathrm{~km}^{2}$, est surtout constituée de tundras, au climat relativement froid et pluvieux, avec une faune et une flore malingres. Les hôtes principaux d'E. multilocularis sont le renard arctique, Alopex lagopus, et le campagnol nordique, Microtus aconomus, qui habitent la majeure partie du terrain et dont les populations sont cycliques avec une fréquence de 3 à 4 ans. L'étude, entreprise en 1956, a comporté une première phase intensive de 4 ans, au cours de laquelle les populations des hôtes et des parasites, et le milieu, ont été examinés. Puis, pendant 11 ans, les résultats des premières investigations ont été testés à plusieurs reprises sur le terrain et au laboratoire. Les efforts ont porté principalement sur l'influence des cycles des populations des hôtes naturels sur la fréquence du parasite. Aussi, des études comparées ont-elles été entreprises sur le cycle de vie synanthropique, qui inclut les chiens de traîneaux et les campagnols, dans le plus grand village des Esquimaux de l'île. Des rapports ultérieurs donneront les résultats de ces recherches.

The larva of Echinococcus multilocularis Leuckart, 1863, was first recognized as the causative agent of alveolar hydatid disease in man by Virchow (1856), but the relationship of this organism to its adult form in canids was controversial for about a century thereafter. Through the efforts of Rausch and Schiller (1954), Rausch (1956), and Vogel (1955, 1957), that problem of relationship was solved, and a greater understanding of taxa within the genus Echinococcus was developed (Rausch, $1953 \mathrm{~b}$; Rausch and Nelson, 1963). A further determination was that E. multilocularis was actually widely distributed over most of northern Eurasia and parts of northern North America, whereas it was thought earlier to occur only in parts of central and eastern Europe (see review by Rausch, 1967). Its occurrence outside of Eurasia was first recognized in 1950, when it was found on St. Lawrence Island in the Bering Sea 
(Rausch and Schiller, 1951; Rausch, 1952). It has since been found in several other localities in Alaska (Rausch, 1956; Fay and Williamson, 1962) and northern Canada (Choquette et al., 1962), as well as in south-central Canada and north-central United States (Leiby and Olsen, 1964 ; Hnatiuk, 1966 ; Lee, 1969 ; Leiby et al., 1970 ; Holmes et al., 1971 ; Rausch and Richards, 1971). In none of those places, however, is this parasite as abundant and successful as it is on St. Lawrence Island, and for this reason and others to be considered later, that island was selected as an area for intensive study of the ecology of $E$. multilocularis in a relatively undisturbed environment. Preliminary investigations of the ecology of $E$. multilocularis were carried out there from 1950 to 1955 (Rausch and Schiller, 1956). In the present study. begun in 1956, as a natural extension and expansion of that work, primary emphasis was placed on the influence of population cycles of the principal hosts on the abundance of the parasite. Results of the earlier work suggested that this was an appropriate approach to an understanding of the system that favored such unusual abundance.

The present investigation began with a 4-year intensive phase and was concluded with an 11-year follow-up phase, in which some aspects of the environment were studied in greater detail and the validity of earlier results was tested by further sampling and experimentation (Fay and Rausch, 1966; Fay, 1970). The purpose of this report is to introduce that 15 -year study by describing the major physical and biotic characters of the island, by reviewing the life cycle of the parasite and its natural hosts, and by surveying the rationale and constraints around which the study was planned and carried out. Subsequent reports in this series will present the findings and discuss their interpretation and application.

\section{Physical aspects of the study area}

St. Lawrence Island (Fig. 1) is located in the north-central part of the Bering Sea, about $65 \mathrm{~km}$ east of the southwestern tip of the Chukotskii Peninsula, USSR, $210 \mathrm{~km}$ west of the delta of the Yukon River, Alaska, and about $350 \mathrm{~km}$ south of the Arctic Circle. This island, surrounded by the shallow waters of the intercontinental shelf, is generally acknowledged to have had broad terrestrial connections as recently as 10,000 years ago with both the Eurasian and the North American continents, as a part of the Bering Land Bridge (Hopkins, 1967). Its present faunal and floral relationships with the continental biota (e.g. Rausch, $1953 a$; Young, 1971 ; Sealy et al., 1971) are largely products of those connections. The island is about $160 \mathrm{~km}$ long, on a generally east-west axis, and ranges from 16 to $45 \mathrm{~km}$. in northsouth width. Its area (approximately 5,000-sq-km) is mainly of low relief. under $75 \mathrm{~m}$ in elevation, with many small lakes and a few mountainous areas up to $630 \mathrm{~m}$ high. 
For about 8 months of each year, the island is snow-covered, and for most of that period, it is surrounded by the seasonal ice pack. This ice is continuous to the north with the permanent ice pack of the Arctic Ocean, and in mid- to latewinter, extends also some $350 \mathrm{~km}$ south of the island, to the edge of the intercontinental shelf. In the snow-free period, June to September, tundra vegetation flourishes on the active layer of soil. The ground may thaw by late-summer to a depth

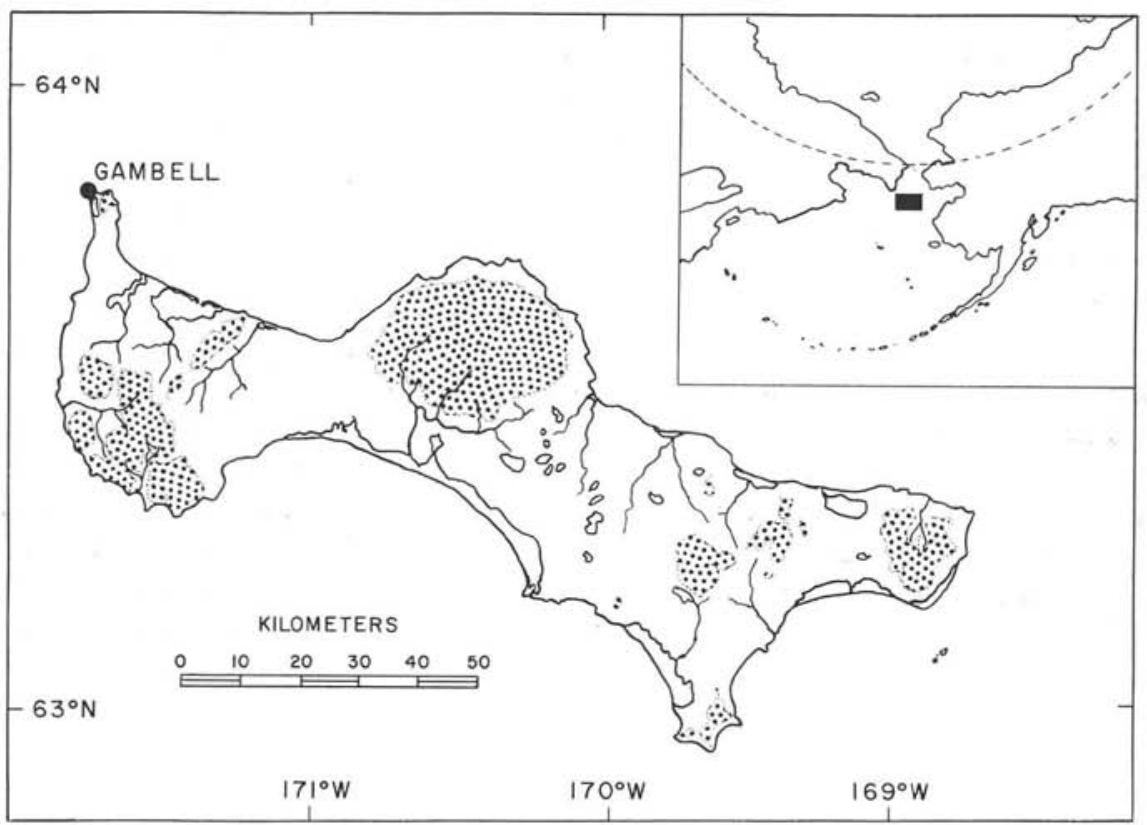

Fig. 1. - St. Lawrence Island, Bering Sea, showing the major lakes and rivers and the mountainous areas above $100 \mathrm{~m}$ in altitude (stippled). The location, relative to continental Alaska, northeastern USSR, and the Arctic Circle, is shown in the inset

(L'île St-Laurent, mer de Bering, montrant les lacs et fleuves majeurs et les étendues montagneuses au-dessus de $100 \mathrm{~m}$ (pointillé). La situation géographique, relative à l'Alaska continentale, au nordest de l'U.R.S.S., et au Cercle Arctique, est montrée dans l'encadrement

of $1 \mathrm{~m}$ where it is widely exposed or to about $0.3 \mathrm{~m}$ where the surface vegetation forms a dense, insulating mat. The surface of the soil is usually very wet throughout the summer, for the low relief inhibits runoff and the permanently frozen layer beneath prevents percolation.

The climate is cold and damp, with frequent and persitent high winds. Air temperatures recorded by the U.S. Weather Bureau (1953), during a 10-year period of observation at Gambell on the northwestern tip of the island, ranged from $-34^{\circ}$ to slightly above $0^{\circ} \mathrm{C}$ for the coldest months, January to March, and from $-6^{\circ}$ to about $18{ }^{\circ} \mathrm{C}$ for the warmest months, June to August (Fig. 2). The relative humi- 
dity in winter was mostly between 75 and 85 per cent and in summer 90 to 95 per cent. The mean hourly wind velocity in summer was about $6 \mathrm{~m}$ per second; in winter it was about $10 \mathrm{~m}$ per second. The highest recorded velocity was $44.7 \mathrm{~m}$ per second $(100 \mathrm{mph})$ in October.

Precipitation in amounts of $0.25 \mathrm{~cm}$ or more fell on 150 days of the year, and trace amounts were registered on another 150 days. Though frequent in
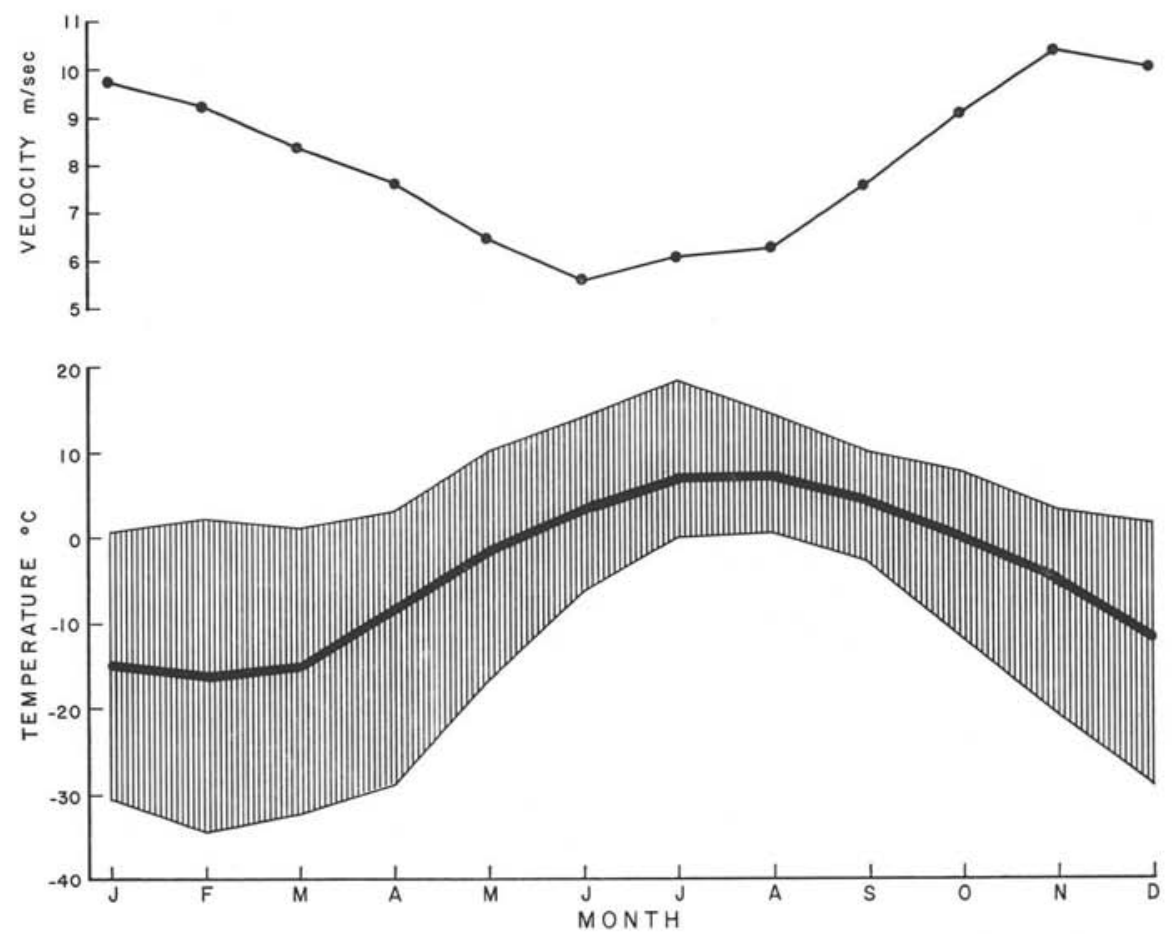

FIG. 2. - Monthly mean wind velocities (upper) and surface air temperatures (lower, heavy line) measured by the Weather Bureau, at Gambell for the period 1943 to 1953. Cross-hatching indicates the range of extremes of temperature)

(Vitesses moyennes du vent par mois (ligne supérieure) et températures de l'air en surface (en bas, vitesses, trait fort), mesurées par le Weather Bureau à Gambell pendant la période de 1943 à 1953. La zone en hachures indique l'étendue des extrêmes de température)

occurrence, the amount of precipitation was usually low, and the annual total ranged from only 27 to $79 \mathrm{~cm}$, with a mean of about $40 \mathrm{~cm}$, most of which was snow. The annual snowfall ranged from 80 to $400 \mathrm{~cm}$; however, the depth of snow on the tundra during the 15 years of this study seldom exceeded $60 \mathrm{~cm}$, for the high winds tended to blow it away and to drift, sculpture, and greatly consolidate it. Throughout the winter, the snow in most of the areas visited was firm enough to support a man or a loaded sledge. 
Snow conditions are important in the ecology of northern animals, and the density of the snow is known to affect its insulating capacity (e.g. see Formozov, 1946 ; Fuller et al., 1969). Thus, it was assumed when this study began that the wind-compacted snow of St. Lawrence Island would be relatively poor insulation and, consequently, that the tundra biota would occasionally be exposed to low temperatures. Since the air temperatures in winter in this maritime climate are much higher than those of nearby continental areas, it was assumed further that the sub-nivian microclimate would be less severe than in continental areas at the same latitude. Subsequent measurements of temperature under the snow did not support the latter

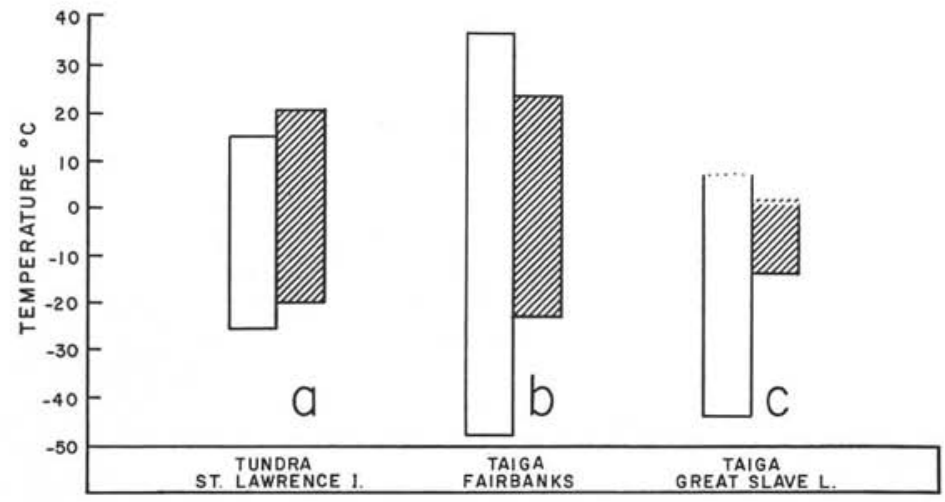

Fig. 3. - Comparatives ranges of air (open blocks) and ground surface (cross-hatched) temperatures in tundra and taïga situations at comparables latitudes: $a$ ) from Table $1 ; b$ ) after Pruitt (1957); c) after Fuller et al. (1969)

[Températures comparées de l'air (blocs ouverts) et de la surface du sol (hachures) dans la toundra et la taïga à des latitudes comparables : $a$ ) Tableau $1 ; b)$ de Pruitt $(1957) ; c)$ de Fuller et al. (1969)]

assumption, for the high winds had a greater influence than was expected, overriding the insulative effects of any but the deepest drifts. Within 24 hours after wind velocity rose to about $13.5 \mathrm{~m}$ per second or more (measured $10 \mathrm{~m}$ above the ground), the temperature at the ground level, under a 30 to $60 \mathrm{~cm}$ layer of snow, tended to become equal to that of the air $1 \mathrm{~m}$ above the ground. With diminution of velocity below about $10 \mathrm{~m}$ per second, ground surface temperatures remained relatively stable at the last level attained in the preceding windy period. Since high winds occurred very frequently during the winter, the temperatures in the sub-nivian environment, most of the time, tended to approximate those of the air above the snow (Table I). While the latter were moderate, relative to those in the taiga at comparable latitudes, the range of sub-nivian temperatures was about the same as in the taiga (Fig. 3). Whereas the small animals of the comparatively windless taiga are provided by the snow with ample insulation in most winters (e.g. Johnson, 1951; 
Pruitt, 1957; Fuller et al., 1969), those of the windy tundra seem to have little thermal protection beneath the snow, other than from the direct, chilling effects of the wind itself. Temperatures in the soil, at a depth of $20 \mathrm{~cm}$ beneath the surface (i.e. at the usual maximal depth of small rodents' burrows and sub-surface nests) also were remarkably low and only slightly more stable than those on the surface of the ground (Table I).

\section{Table I}

SURFACE AND SUB-SURFACE TEMPERATURES $\left({ }^{\circ} \mathrm{C}\right.$ ) MEASUREd IN SEVERAL LOCATIONS IN AND NEAR Gambell, St. Lawrence Island, during 1957 to 1968 . The number of observations is SHOWN IN PARENTHESES

$\mathrm{T}^{\circ}$ en ${ }^{\circ} \mathrm{C}$ du sol et du sous-sol mesurées dans plusieurs localités de Gambell et ses environs, à l'Tle Saint-Laurent, de 1957 à 1968. Le nombre des observations est indiqué entre parenthèses.

\begin{tabular}{|c|c|c|c|c|c|c|c|c|}
\hline \multirow{3}{*}{ Month } & \multicolumn{5}{|c|}{ Surface } & \multicolumn{3}{|c|}{ Sub-surface } \\
\hline & \multirow[t]{2}{*}{$\begin{array}{l}\text { No. } \\
\text { obs. }\end{array}$} & \multicolumn{2}{|c|}{$\begin{array}{c}\text { Air } 1 \mathrm{~m} \\
\text { above ground }\end{array}$} & \multicolumn{2}{|c|}{$\begin{array}{l}\text { Soil } \\
\text { surface }\end{array}$} & \multirow[t]{2}{*}{$\begin{array}{l}\text { No. } \\
\text { obs. }\end{array}$} & \multicolumn{2}{|c|}{$\begin{array}{l}20 \mathrm{~cm} \text { beneath } \\
\text { soil surface }\end{array}$} \\
\hline & & Min. & Max. & Min. & Max. & & Min. & Max. \\
\hline Jan. . . & (25) & -26.0 & 0.0 & -20.5 & -5.7 & $(0)$ & {[} & - \\
\hline Feb. . . & $(0)$ & $\overline{00}$ & & & & ( 0$)$ & & \\
\hline Mar. . & (11) & -20.0 & 2.0 & -20.0 & -3.7 & ( 5$)$ & -19.6 & -17.5 \\
\hline Apr. .. & (22) & -15.5 & 4.1 & -9.0 & -3.6 & (1) & -5.4 & \\
\hline May .. & (27) & -8.0 & 1.8 & -5.1 & 0.6 & ( 8 ) & -2.8 & -1.3 \\
\hline June ... & (17) & 3.9 & 14.4 & 4.2 & 20.2 & ( 0$)$ & & \\
\hline July .. & (18) & 5.8 & 10.6 & 5.8 & 9.0 & (12) & 6.4 & 8.0 \\
\hline Aug. .. & (2) & 6.9 & 7.0 & 7.0 & 7.2 & ( 2$)$ & 6.7 & 7.0 \\
\hline Sept. .. & (28) & -2.5 & 12.0 & -1.0 & 12.5 & ( 0$)$ & - & - \\
\hline Oct. . . & ( 0$)$ & $\bar{n}$ & & & & ( 0$)$ & $\longrightarrow$ & - \\
\hline Nov, . . & (18) & $-5,8$ & $-1,7$ & -7.0 & - 3.7 & ( 0$)$ & $\longrightarrow$ & 一 \\
\hline Dec. .. & ( 2) & - & & -6.3 & -6.6 & ( 0$)$ & $\cdot-$ & - \\
\hline
\end{tabular}

The spring meltoff of snow at the lower elevations began usually about mid-May and continued through early June. In the mountainous areas it was delayed about 1 month. Most of the lake and river ice was gone by the end of May. Rapid subnivian meltouts occurred about rocks, animal bones, tufts of vegetation, and other prominent objects in mid-May, and by late-May the peat mounds, boulders, and other elevated areas were exposed. The release of water during the meltoff resulted in flooding of all low lying areas, and many temporary ponds developed, which usually persisted until after the snow was gone.

Surface temperatures of the soil in summer were generally about the same as air temperatures or slightly higher, due to insolation. Sub-surface temperatures were generally lower, as a consequence of their proximity to the permanently frozen layer. 
The first frosts at low elevations usually occurred about September 1, and the first persistent snow about 1 month later. Lake and river ice was ordinarily complete in extent by November.

\section{Biotic aspects of the study area}

The known biota of St. Lawrence Island comprises about 250 species of vascular plants (Young, 1971), 141 species of birds (Sealy et al., 1971), and 12 species of terrestrial mammals, including 7 that are indigenous, 2 that occasionally reach the island by way of the ice pack, and 3 that were introduced by man (Rausch, 1953 a). At least 15 species of marine mammals, including the polar bear, Ursus maritimus (Phipps), 7 kinds of Pinnipedia, and 7 kinds of Cetacea, frequent the shores and coastal waters (Murie, 1936; Fay, unpublished). No other forms of life, to my knowledge, have been thoroughly inventoried on the island. The known fauna and flora are depauperate, relative to those of comparable areas on the nearby Alaskan and Siberian mainlands, as is characteristic of insular biota (Mayr, 1965).

The vegetation of the island is mainly herbaceous and, for the most part, is less than $20 \mathrm{~cm}$ high. Young (1971) recognized 4 major types of habitats : first, bog and wet tundra, which is most prevalent and occupies most of the lowlands (Fig. 4). It extends also well up into the mountains, where solifluction terraces impede drainage. This is the principal habitat of the northern or root vole, Microtus oeconomus Pallas, and the masked shrew, Sorex cinereus Kerr. Vegetative cover of the soil in this type is virtually 100 per cent and is made up mainly of grasses and sedges, with a Sphagnum understory. The second type, alpine and fell-field, comprises about 30 per cent of the total land area and supports a relatively sparse vegetative cover of vascular plants, though often a dense cover of lichens (Fig. 6). This is the habitat of the collared lemming, Dicrostonyx groenlandicus (Traill), and northern red-backed vole, Clethrionomys rutilus Pallas, and is, very often, the denning site of the polar or arctic fox, Alopex lagopus Linnaeus. In general, this

FIG. 4. - Wet tundra of the southern coastal plain with many small, shallow lakes. This kind of flat, marshy terrain is typical of about half of the island and is seen here from an elevation of about $30 \mathrm{~m}$. The terrain in the foreground is mesic tundra on an ancient wave-cut escarpment

(Tundra mouillée de la côte méridionale de l'île St-Laurent, avec beaucoup de petits lacs peu profonds. Ce type de terrain plat et marécageux, vu ici d'une élévation près de $30 \mathrm{~m}$, est caractéristique d'approximativement la moitié de l'île. Le terrain à devant est mesic tundra dans un escarpement ancien, coupé par les vagues)

FIG. 5. - River valley of wet tundra, flanked by higher, better drained mesic tundra and fell-field habitats, in the southwestern interior. A few snow patches remain on the hills in the background for all or most of summer

(Vallée d'un fleuve avec tundra mouillée, bordée par mesic tundra et par fell-fields, habitats plus élevés et mieux égouttés, dans le sud-ouest de l'intérieur de l'île. Quelques morceaux de neige restent dans les collines au fond pendant l'été ou la plupart de cette saison)

FIG. 6. - Alpine and fell-field habitats at an elevation of about $200 \mathrm{~m}$ on the southwestern coast. Snow patches at left. This and the preceding photos taken in late July, 1959

(Habitats alpins et de fell-fields, à une élévation près de $200 \mathrm{~m}$, au sud-ouest de la côte. Morceaux de neige à gauche. Cette photographie et celles qui précèdent ont été faites vers la fin de juillet 1959) 


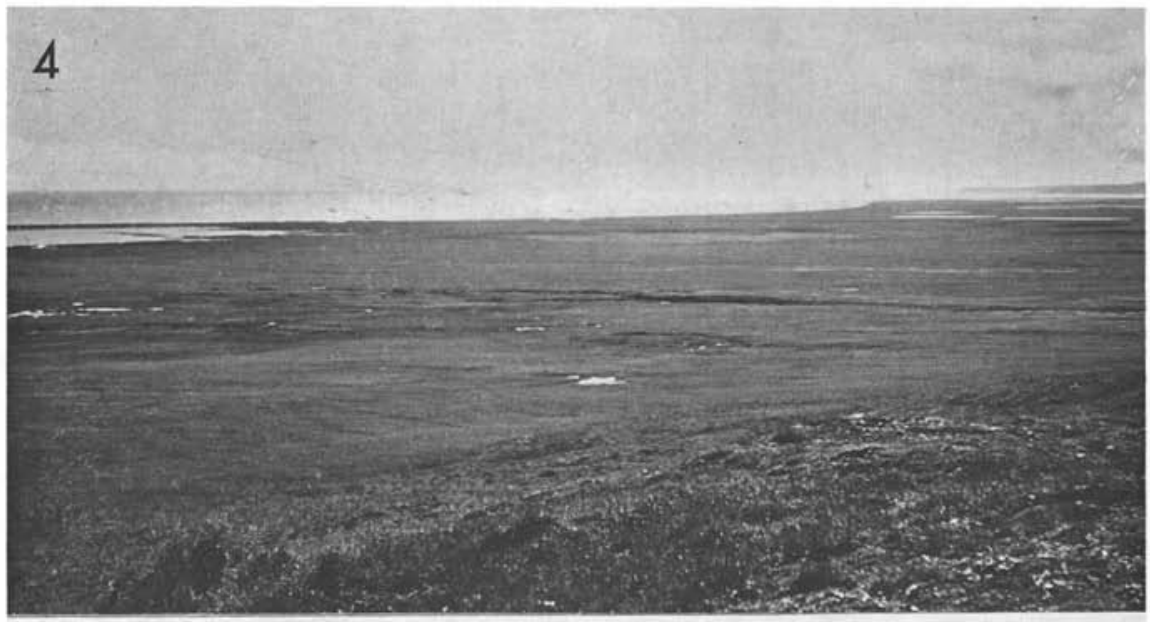

5

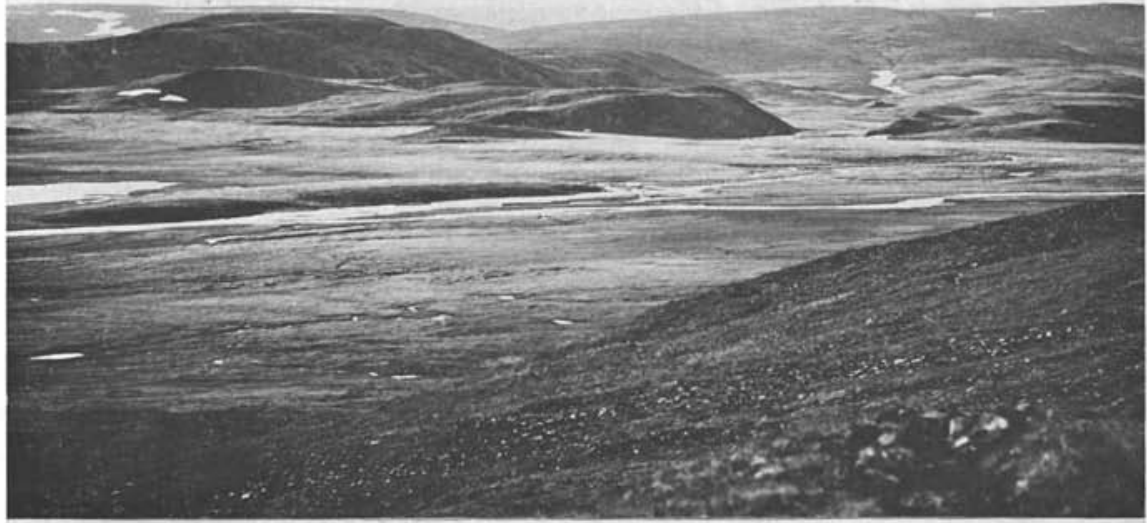

6

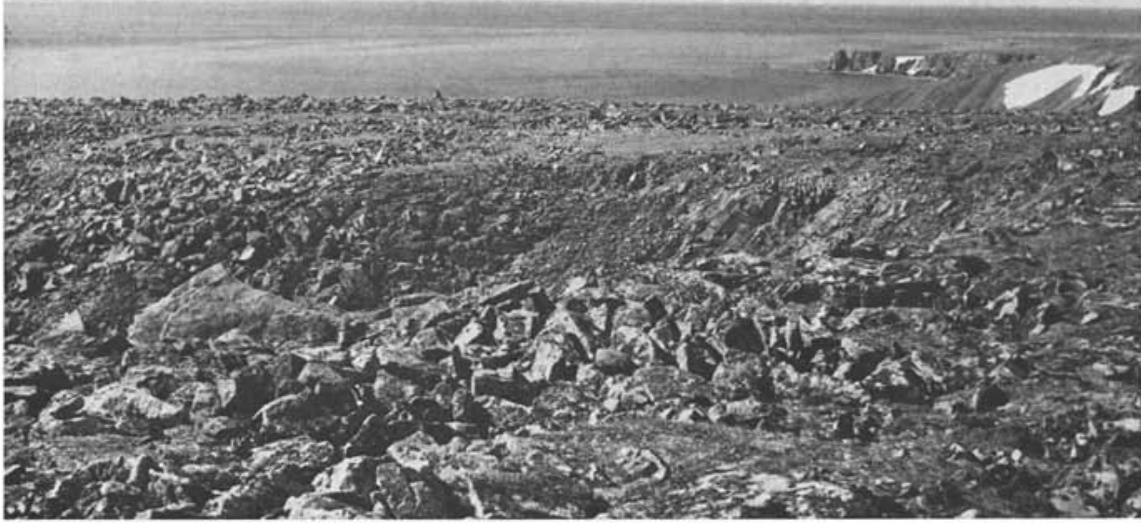


type is characteristic of elevations above $100 \mathrm{~m}$, though it extends down to the sea in a few areas. The third type, mesic tundra, with a wide variety of sub-habitats, each with good drainage and a deep active layer of soil, is the principal habitat of the arctic ground squirrel, Citellus parryi (Richardson) and the usual denning site of the arctic fox (Fig. 5). Mesic tundra supports the greatest variety of flowering plants and though small in area (5 to 10 per cent of the total), is of major importance to the root vole as a refuge during spring floods and in periods of low population density. Fourth are the aquatic habitats, which make up a large part of the area but support a poor vegetative assemblage and are relatively unimportant as mammalian habitats. Of several minor habitats considered, the most important in the present context are the human habitation sites, some of which cover several hectares and each of which supports an unusually dense population of root voles. Such sites, mostly several hundred to about 3,000 years old, are scattered along the coasts, and each is characterized by a luxuriant stand of nitrophilous vegetation, made possible by the slow release of nutrients from the abundant organic refuse in the soil.

The avifauna of the island has been inventoried in some detail by several workers (see reviews by Fay and Cade, 1959 ; Sealy, et al., 1971) and was regarded as important in this study, in that birds comprise a major supplementary source of food for the principal definitive host of $E$. multilocularis, the arctic fox. They are important also in that they include several predatory species that compete with the foxes for food. Members of the families Alcidae and Anatidae, which make up the bulk of the avifauna in terms of both numbers and biomass (Fay and Cade, 1959), are the principal avian prey of the foxes (Stephenson, 1970). The predatory birds are mainly owls (Strigidae) and jaegers (Stercoraridae). The avifauna of the island may be characterized as low arctic maritime, with a very high proportion of aquatic birds and a very low proportion of passerine birds. Nearly all of the birds are seasonal in occurrence, nesting and rearing their young there during the summer and departing southward in September.

The mammalian elements of the biota that are of primary importance to E. multilocularis are the arctic fox, the sledge dog, Canis familiaris Linnaeus, and the house cat, Felis domesticus Linnaeus, which harbor the adult cestodes, and the root vole, red-backed vole, masked shrew, and man, which harbor the larvae. The ground squirrel, collared lemming, and reindeer, Rangifer tarandus Linnaeus, that inhabit the island may be exposed frequently to $E$. multilocularis infection but probably do not play an important role in its ecology (Rausch and Schiller, 1956). Of 217 ground squirrels from the island that were examined in the course of this work and that of Rausch and Schiller, 8 had hepatic lesions that superficially resembled larvae of E. multilocularis, but each was found histologically to be non-echinococcal in origin (Ohbayashi et al., 1971). The collared lemming is the rarest of the indigenous mammals and, evidently, is of little importance in the herbivore-carnivore segment of the food web on the island (Stephenson, 1970). None of the 20 specimens obtained in this study harbored larvae of E. multilocularis, though it is conceivable that some would have been found infected had a larger series been examined. Since lemmings 
of the genus Dicrostonyx show a wide range of susceptibility to E. multilocularis infection (Ohbayashi et al., 1971), it is conceivable also that the St. Lawrence Island form is refractory to this parasite. Of the reindeer on the island, only 3 have been examined. One of these showed hepatic lesions suggestive of helminthic infection, but none of the lesions was certainly identifiable as being of echinococcal origin (Rausch and Schiller, 1956). Attempts to infect reindeer experimentally with E. multilocularis have yielded only negative results (Rausch, unpublished).

Two species of mammals that occasionally reach the island via the ice pack, as confirmed by specimens, are the brown bear, Ursus arctos Linnaeus, and the red fox, Vulpes vulpes Linnaeus (Geist, 1934; Rausch, 1953 a) ; apparently, one wolf, Canis lupus Linnaeus, was sighted but never obtained (Murie, 1936). None of these species is important in the ecology of E. multilocularis in this locality, by reason of extreme scarcity. The bear, at least, is probably not a suitable host.

The aquatic mammals (whales, seals, and walruses) found about the island also are of some importance in the ecology of the parasite, in that they comprise, as carrion, a major source of food for the definitive host (arctic fox) in winter, when other foods are scarce or difficult to obtain (Schiller, $1954 a$; Fay, unpublished).

In general, the terrestrial mammalian fauna of St. Lawrence Island resembles that of the continental tundra but lacks some of the major components, such as the brown lemming, Lemmus sibiricus Kerr, the red fox, the wolf, and members of the family Mustelidae. While the indigenous voles and foxes may in part, fill the niches normally occupied by such components, the substitution is far from complete. For example, the root vole seems to occupy all of the habitats that would be utilized by Lemmus, but it is evidently not comparable as a prey species, for the avian predators that are so numerous and important in the continental tundra ecosystem (e.g. see Pitelka et al., 1955) are relatively uncommon as breeders on the island (Fay and Cade, 1959 ; Sealy et al., 1971).

\section{Natural life cycle of Echinococcus multilocularis}

E. multilocularis inhabits the small intestine of red and arctic foxes and, in the larval stage, the liver of small, mouse-like rodents. Individuals of the Alaskan strain of this cestode develop to the gravid stage in about 32 days in the intestine of the definitive host, whereupon they begin to release segments, each of which contains about 200 eggs (Rausch and Schiller, 1956). The adult cestodes, usually about $2 \mathrm{~mm}$ long (range : 1.2 to $4.5 \mathrm{~mm}$ ) with 5 or 6 strobilar segments (Rausch and Bernstein, 1972), are minute but occur commonly in populations of 200 to 300 per red fox and 10,000 to 25,000 per arctic fox (Rausch and Richards, 1971). They are known to produce gravid segments for at least 3 to 3.5 months (Rausch and Schiller, 1956). When passed in the feces of the fox, the gravid segments undergo rhythmic contractions, forcibly expelling their eggs over the nearby soil and vegetation, as well as in and on the feces (Fay, unpublished). From there, the eggs may 
be further transported by wind, water, and insects (Schiller, 1954 b). Though minute (30 to $38 \mu$ in greatest diameter: Rausch, $1953 \mathrm{~b}$ ), they have a specific gravity of about 1.118 (Meyers, 1955) and tend to sink to the bottom in quiet bodies of water. The eggs probably remain infective for several months in the cool, damp climate of maritime areas such as St. Lawrence Island (e.g. see Thomas, 1955 ; Schiller, 1955), but the exact survival time under natural conditions is as yet unknown. Upon ingestion by a vole or other mouse-like rodent, presumably on vegetation or insects consumed as food, the hexacanth embryo is released from the embryophore by digestive secretions in the duodenum (Rausch, unpublished) and, after penetrating the intestinal wall, is transported to the liver, presumably via the hepatic portal circulation. In the liver, the embryo lodges in the hepatic parenchyma, usually just beneath the capsule, where its development into the primary vesicle is completed in 4 to 12 days, depending on the species of host (Ohbayashi et al., 1971). The primary vesicle gives rise to other vesizles by exogenous budding, and they in turn give rise to others, etc., resulting in a larval mass made up of hundreds of contiguous vesicles, which may occupy more than half of the invaded hepatic lobe. Growth of the larva from the single primary vesicle to the compound, multivesicular stage with infective protoscolices, may be completed in as little as 2 months or as long as 7 months, depending on the conditions for growth in the host (Ohbayashi et al., 1971 ; Fay, 1970 and unpublished). The number of protoscolices within a larval mass derived from a single embryo is highly variable within and between species of hosts (Leiby et al., 1970 ; Ohbayashi et al., 1971) but may amount to several thousand (e.g. see Rausch and Richards, 1971). The fox, on ingesting a vole that harbors such a fully developed larva, may release some of the protoscolices by mastication, but most are freed from the vesicles by digestive maceration in the stomach and intestine. In the small intestine these become activated, after which they evaginate and attach to the intestinal mucosa, mostly in the jejunum (Rausch, unpublished). There, they develop into adult cestodes in about 32 days, and the life cycle is completed.

\section{Natural history of the definitive host}

The principal definitive host of E. multilocularis at high latitudes is the arctic fox, which is circumpolar in distribution. This animal, an inhabitant of the open tundra, in effect supplants the red fox as the principal mammalian predator on small rodents and birds of the Arctic. The arctic fox is mainly coastal in distribution, seldom ranging far inland, but travels widely over the ice pack in winter. In Alaska, it occurs regularly from the vicinity of the Kuskokwim estuary and the Pribilof Islands northward to the Arctic and has been introduced on several islands in the Aleutian chain (Hanna, 1920 ; Preble, 1923 ; Murie, 1936, 1959 ; Bee and Hall, 1956 ; Chesemore, 1967). It is the only indigenous fox on the Pribilofs, St. Matthew, and St. Lawrence islands, whereas on Nunivak Island and along the coast of western and northern Alaska, its range overlaps that of the red fox. 
The young are born usually in May or June in a den prepared by the parents or on the tundra near the den. They remain near the den for most of the summer, and food is brought to them by both parents (see review by Braestrup, 1941). The number of young per litter is highly variable, the mean being usually less than 10 and the maximum more than 20. Their rate of survival also varies widely, apparently depending on the food supply (Braestrup, 1941 ; Macpherson, 1969). The pups attain independence by September and are fully grown and sexually mature by the following spring. Copulation takes place from February to May (usually March and April), and the gestation period is about 52 days (Barabash-Nikiforov, 1938; Demen'tev, 1955).

The arctic fox is remarkably omnivorous but is primarily adapted to exploitation of vole and lemming populations of the tundra. Since these rodents undergo cyclic fluctuations in numbers, with a periodicity of 3 to 4 years, the foxes also show a 3to 4-year cycle of abundance (e.g. see Elton, 1942). In many areas they rely on birds as a major supplement to their diet and, in winter, on the availability of carrion (Braestrup, 1941). They are known to store food in caches (Pedersen, 1930 ; Stephenson, 1970) and to scavenge readily in areas of human habitation, particularly when natural foods are scarce (Judge, 1912).

One of the principal causes of natural mortality of arctic foxes is epizootic rabies, which is prevalent throughout their range (e.g. see Frenchen, 1935 ; Rausch, $1958 a$, 1972). In many areas, a high toll is taken also by trappers, mainly Eskimos and other native peoples of the polar region, for whom the income from sale of the skins is a major part of the subsistence economy.

The only other natural definitive host of E. multilocularis in Alaska, so far as is known, is the red fox (Rausch, 1956). Although this fox is the most important host of the parasite in other areas (Rausch, 1967 ; Lukashenko, 1971), it will not be considered further in this report series because of its scarcity and transient status in the study area, as noted earlier.

The most important definitive host in the campestral or synanthropic cycle of E. multilocularis in rural Alaska is the domestic dog, which, during most of this study, was present in numbers exceeding those of the human population. In recent years, with the availability of dependable mechanized transportation, the use of the dogdrawn sledge has greatly diminished, and the number of animals maintained for this purpose has been reduced to less than one-tenth of the former level in most areas. For the most part, the adult dogs are tethered in and around the villages, while the young dogs under 6 months old are allowed to roam freely. On St. Lawrence Island, these animals are maintained on a diet consisting mainly of walrus and seal meat, but they have many opportunities to catch and eat voles, as their helminth fauna attests. Up to 25 per cent of the dogs have been known to harbor taeniid cestodes, principally E. multilocularis, which they could have acquired only from ingestion of infected voles (Rausch and Schiller, 1956; Fay and Rausch, unpublished). A few dogs and house cats also are kept as household pets on the island. 


\section{Natural history of the intermediate host}

The intermediate hosts of E. multilocularis are mostly small, cricetid rodents of the subfamily Arvicolinae Gray, 1821 (syn. Microtinae Cope, 1891 : see Kretzoi, 1962), notably several kinds of voles of the genera Microtus Schrank and Clethrionomys Tilesius (Abuladze, 1964; Rausch, 1967). In Alaska, natural infections have been found in 3 species of arvicoline rodents: the root vole, $M$. oeconomus (St. Lawrence Island, Wales, Hooper Bay, and Point Hope: Rausch and Schiller, 1951 ; Rausch, 1967 ; Ohbayashi et al., 1971 ; Rausch, unpublished), the northern red-backed vole, C. rutilus (St. Lawrence Island: Rausch, 1952), and the brown lemming, L. sibiricus (St. George Island: Ohbayashi et al., 1971). An insectivore, the masked shrew, S. cinereus, has been found infected repeatedly on St. Lawrence Island (Thomas et al., 1954 ; Ohbayashi et al., 1971). A natural infection in a ground squirrel, C. parryi also was reported from that area by Thomas et al. (1954), but it apparently was not verified by histological study; no such infections have been found in subsequent, more extensive collections, as noted earlier.

The intermediate host of greatest importance on St. Lawrence Island is the root vole, which is the most abundant small mammal on the island and is the staple food of the arctic fox population (Rausch, $1953 a$; Rausch and Schiller, 1956 ; Stephenson, 1970). The root vole is widely distributed across northern Eurasia, within most of the range of E. multilocularis (cf. Ognev, 1950 ; Rausch, 1967). In North America, this vole is found only in Alaska and northwestern Canada, to which it evidently spread after the last (Wisconsin = Würm) glaciation (Rausch, 1963). It is typically an inhabitant of damp to wet, grassy lowlands and promptly invades seasonally flooded land following recession of the water (Bee and Hall, 1956; Tast, 1966).

In northern Alaska, the young are born from June to August, and litter size ranges from a mean of about 8 early in the summer to 5 late in summer (Bee and Hall, 1956). The gestation period is 20 to 22 days (Frank and Zimmerman, 1956), and a single female may produce as many as 5 litters per year, though the usual number is 2 or 3 (Tast, 1966). Young of the first litter (late May-early June) become sexually mature and productive before the end of the summer, while those of the later litters do not mature until the following summer (Karaseva et al., 1957). Overwintering populations are made up mainly of these immature animals, in colonies of up to 10 individuals each (Tast, 1966).

The diet of the root vole in summer comprises sedges, grasses, and a wide variety of forbs. Some of the plants most commonly utilized on St. Lawrence Island are Arctogrostis latifolia (R. Br.), Calamagrostis canadensis (Michx.), Elymus arenarius L., Rumex arcticus Trautv., Cochlearia officinalis L., Sedum rosea (L.), Saxifraga punctata L., Polemonium boreale Adams, Artemisia tilesii Ledeb., and Petasites frigidus (L.). Winter foods there include the stems and basal shoots of $C$. canadensis, Carex aquatilis Wahlenb., and $A$. tilesii, which are cached by the voles in underground 
chambers, and the standing parts of these and of $C$. officinalis. Winter caches, up to 4 or 5 liters in volume and containing roots, shoots, and seeds, have been found in other areas by Bee and Hall (1956) and Murie (1959).

\section{The epidemiology of Echinococcosis on St. Lawrence Island}

The first definitely autochthonous cases of $E$. multilocularis infection in man in North America were diagnosed in residents of St. Lawrence Island during the 1950's (Rausch, 1960); subsequently, several additional cases were detected there and on the mainland of Alaska (West et al., 1963 ; Wilson and Rausch, unpublished). E. multilocularis infection in man is comparable to that in the intermediate host (larval stage, developing in the liver) but differs in that the larval mass is inhibited from completing its development and remains in the proliferative stage indefinitely (Rausch and Wilson, 1973). Thus, it continues to invade and destroy the hepatic parenchyma, and retrogressive changes within the mass result in necrosis of the central portion (Rausch, $1958 \mathrm{~b}$ ). Most exposures are believed to occur in childhood, but the rate of growth of the larva is apparently so slow that clinical signs of the disease do not usually become evident until adulthood or even middle age (see review by Lukashenko, 1971).

Exposure to infection in man, as in the voles, is by ingestion of the eggs of the cestode, i.e. by canine fecal contamination of food, water, or other materials taken into the mouth. The degree of risk of exposure is, therefore, directly proportional to the abundance of eggs in the human environment and to the efficacy of mechanisms for fecal contamination of ingestable materials. While the possibilities for contamination of ingestables either directly or by wind, insects, and other mechanical means are probably no greater on St. Lawrence Island than they are elsewhere in rural Alaska, the risk of human exposure to E. multilocularis infection on the island seems unusually high, because of the greater abundance of infected foxes and the abundance of potentially infected dogs in the village areas (Rausch and Schiller, 1956). This prediction is supported by the finding of higher per capita rates of infection there than anywhere else in Alaska (Rausch, 1972). Contamination of the home, through handling and processing of fox furs and through the keeping of dogs and cats as household pets, is regarded as particularly hazardous (Rausch and Schiller, 1956; Rausch, $1958 \mathrm{~b}$ ). The more rapid development of larvae and the higher rates of infection in voles from the villages than in those from the tundra (Fay, 1970 and unpublished) suggest that the risk of human infection in and around the human habitations is greater than it is elsewhere.

In the early stages of investigation (1950-55), it was recognized that the infection rates in the foxes and voles were high but rather unstable. In 3 large series of foxes taken at intervals during that period, the proportion of animals harboring the adult cestodes ranged from 40 to 100 per cent, while the infection rate with larvae in 3 large series of voles in the same period, ranged from 2 to 15.5 per cent (Rausch 
and Schiller, 1956). These variations seemed to be closely correlated with fluctuations in the abundance of the hosts, the parasites being least numerous when the hosts were also least abundant and most numerous when the host populations were in the high point of the cycle. This suggested that the risk of human exposure to infection might also vary with the 3- to 4-year population cycles of the voles and foxes.

\section{The long-term study}

With this background, the present study was begun in the winter of 1955-56. The relative simplicity of the biotic environment of the island was recognized as being unusually favorable for intensive work on the ecology of E. multilocularis, and, from the greater abundance of the parasite there than elsewhere, it was evident that the factors which, in combination, favor its proliferation were either present in profusion or that their roles were somehow enhanced by the absence of other, complicating elements. The principal objective was to determine which parts of the ecosystem, singly or in combination, contributed most to the success of this helminth. Initial emphasis was placed on further investigation of the influence of cyclic fluctuations of the vole and fox populations and on the testing of epidemiological theories.

Annual sampling of the host populations was continued, in order to gain further information on infection rates, and this was combined with annual assessments of population densities. In conjunction, studies of the biology and ecology of the voles and foxes on the tundra were begun and were later expanded to include a comparative study in a village situation, where the dog-vole cycle of transmission prevailed. Experimental infections in live-trapped and laboratory-reared voles, under controlled environmental conditions, were utilized in several attempts to duplicate field results and, thereby, to evaluate the influence of certain factors on the welfare of the hosts and their parasites.

More than half the time in the field was devoted to studies on the intermediate hosts and the enzootiology of their infection, since this seemed to offer the greatest return per unit of effort, within the limits of time available (about 2 man-months per year). Most of this work was done within a 1-mile radius of Gambell, which was the base of operations for the entire study. Comparative work on voles in other localities was done on several sites along the southern coast and one in the central interior of the island. These were selected on the basis of their accessibility in summer via small boat (the only transportation in that season) and their being more representative than the Gambell area of conditions on the island as a whole. Continuous investigation and observation were not feasible because of the constraints of time, but a degree of continuity was achieved through bi- and tri-monthly visits to the study area during the first 4 years and by intermittent visits ( 1 to 4 per year) over the next 11 years. At least 1 sample of voles was obtained during each visit, and environmental conditions were measured and noted in detail. 
The annual samples of foxes were obtained during the winter from the catch of the local fur trappers. These were supplemented in spring, summer and fall with specimens taken by the author. Most of the foxes were transported frozen to the Arctic Health Research Center, where they could be studied under conditions that minimized risk to the examiner of exposure to E. multilocularis infection. The field work on foxes was done on and near the southern and central sites, in conjunction with studies of the voles, and in the central and western interior, during several trips on foot and, later, via tracked vehicle. A complementary study of the feeding habits of the foxes in summer in the southern areas was done by R. O. Stephenson (1970).

Much of the field work would not have been feasible without the patient assistance and support of the residents of St. Lawrence Island, to whom I shall be everlastingly grateful. The impetus for this study and much of the knowledge and interpretive effort with which it was designed emanated from Dr. Robert L. Rausch, whose guidance throughout the work and in the preparation of this paper is greatly appreciated.

\section{References}

Abuladze (K. I.), 1964. - Tæniata of animals and man and diseases caused by them. Essentials of Cestodology, vol. IV. K. I. Skrjabin Ed. Acad. Sci. USSR, Helminthol. Lab., Moscow (Israel Prog. Sci. Transl.).

BARABash-Nikiforov (I)., 1938. - Mammals of the Commander Islands and the surrounding sea. J. Mammal., 19: 423-429.

Bee (J.W.) and Hall (E. R.), 1956. - Mammals of Northern Alaska on the Artic Slope. Univ. Kansas Mus. Nat. Hist., Lawrence, Misc. Publ. No. 8.

Braestrup (F. W.), 1941. - A study on the arctic fox in Greenland : immigrations, fluctuations in numbers, based mainly on trading statistics. Med. om Grnl., 131 (4) : 1-101.

Chesemore (D. L.), 1967. - Ecology of the arctic fox in northern and western Alaska. Thesis, Univ. Alaska, Fairbanks.

Choquette (L. P. E.), Macpherson (A. H.) and Cousineau (J. G.), 1962. - Note on the occurrence of Echinococcus multilocularis Leuckart, 1863 in the artic fox in Canada. Canad. J. Zool., 40: 1167.

Dement'ev (N. I.), 1955. - Biology of the arctic fox of Bol'shezemel'skoi tundra. Problems Biol. Fur-bearing Animals, 14: 123 et seq. (Transl. Russ. Game Repts., 3, Canad. Wildlife Serv., Ottawa).

Elton (C.), 1942. - Voles, Mice and Lemmings: Problems in Population Dynamics. Clarendon Press, Oxford.

FAY (F. H.), 1970. - Development of larval Echinococcus multilocularis Leuckart in relation to maturation of the intermediate host. J. Parasit., 56 (no. 4, sec. II, pt. 1) : 97-98. (Abstract).

-, and CADE (T.J.), 1959. - An ecological analysis of the avifauna of St. Lawrence, Island Alaska. Univ. California Publ. Zool., 63: 73-150.

-, and RAusch (R. L.), 1966. - The seasonal cycle of abundance of Echinococcus multilocularis in naturally infected artic foxes. Proc. Ist Internat. Cong. Parasit., 2: 765-766. (Abstract). 
-, and Wili iamson (F. S. L.), 1962. - Studies on the helminth fauna of Alaska. XXXIX. Echinococcus multilocularis Leuckart, 1863, and other helminths of foxes on the Pribilof Islands. Canad. J. Zool., 40: 767-772.

Formozov (A. N.), 1946. - Snow cover as an integral factor of the environment and its importance in the ecology of mammals and birds. Materials Fauna Flora USSR (n.s., zool.), 5 (20): 1-152. (Transl. W. Prychodko and W. O. Pruitt, Jr., Univ. Alberta, Edmonton).

Frank (F.) and Zimmermann (K.), 1956. - Zur Biologie der nordischen Wuhlmaus (Microtus oeconomus). Zeit. f. Säugetierk., 21 : 58-83.

Freuchen (P.), 1935. - Mammals, Part II. Field notes and biological observations. Rept. 5th Thule Exped. 1921-24, 2 (4-5): 68-278.

Fuller (W. A.), Stebirins (L. L.) and DyKe (G. R.), 1969. - Overwintering of small mammals near Great Slave Lake, northern Canada. Arctic, 22 : 34-55.

GeIst (O.W.), 1934. - Brown bear seen on St. Lawrence Island. J. Mammal., 15: 316317.

Hanna (G. D.), 1920. - Mammals of the St. Matthew Islands, Bering Sea. J. Mammal., 1 : 118-122.

HNatiuk (J.M.), 1966. - First occurrence of Echinococcus multilocularis Leuckart, 1863 in Microtus pennsylvanicus in Saskatchewan. Canad. J. Zool., 44 : 493.

Holmes (J. C.), Mahrt (J. L.), and SAMUel (W. M.), 1971. - The occurrence of Echinococcus multilocularis Leuckart, 1863 in Alberta. Canad. J. Zool., 49: 575-576.

Hopkins (D. L.), (Ed.), 1967. - The Bering Land Bridge. Stanford Univ. Press, California.

Johnson (H. M.), 1951. - Preliminary ecological studies of microclimates inhabited by the smaller arctic and subarctic mammals. Proc. 2nd Alaskan Sci. Conf.: 125-131.

Judge (J.), 1912. - The blue foxes of St. Paul and Otter Islands, Alaska. Ann. Rept. Amer. Breeders Assoc., 7 : 275-279.

Karaseva (E. V.), Narskaia (E. V.) and Bernstein (A. D.), 1957. - The economic vole, inhabitant of the vicinity of Lake Nero, Iaroslav District. Bull. Moscow Soc. Nat. (sec. biol.), 62: 5-18.

Kretzor (M.), 1962. - Arvicolidae oder Microtidae? Vertebrata Hungarica, 4: 171-175.

LEE (C.-F.), 1969. - Larval Echinococcus multilocularis Leuckart, 1863 in the southern Interlake area in Manitoba. Canad. J. Zool., 47: 733-734.

LeIBY (P. D.) and Olsen (O. W.), 1964. - The cestode Echinococcus multilocularis in foxes in North Dakota. Science, $145: 1066$.

-, CARney (W. P.) and Woods (C. E.), 1970. - Studies on sylvatic echinococcosis. III. Host occurrence and geographic distribution of Echinococcus multilocularis in the north central United States. J. Parasit., 56: 1141-1150.

LUKashenko (N. P.), 1971. - Problems of epidemiology and prophylaxis of alveococcosis (multilocular echinococcosis): a general review-with particular reference to the U.S.S.R. Internat. J. Parasit., 1: 125-134.

Macpherson (A. H.), 1969. - The Dynamics of Canadian Arctic Fox Populations. Canad. Wildlife Serv., Ottawa, Rept. Ser. No. 8.

MAYR (E.), 1965. - Avifauna : turnover on islands. Science, 150: 1587-1588.

Meyers (H.F.), 1955. - Physical observations on Echinococcus eggs, part. I. J. Parasit., 41 : 1-4. 
MURIE (O. J.), 1936. - Notes on the mammals of St. Lawrence Island, Alaska, 337-346. In Archaeological Excavations at Kukulik, St. Lawrence Island, Alaska by O.W. Geist and F. G. Rainey, Univ. Alaska, Fairbanks.

-, 1959. - Fauna of the Aleutian Islands and Alaska Peninsula. USDI, Fish Wildlife Serv., Washington, No. Amer. Fauna No. 61.

Ognev (S. I.), 1950. - Animals of the USSR and Adjacent Countries. Vol. VII. Acad. Sci. USSR, Moscow.

Ohbayashi (M.), Rausch (R. L.) and FAy (F. H.), 1971. - On the ecology and distribution of Echinococcus spp. (Cestoda: Taeniidae), and characteristics of their development in the intermediate host. II. Comparative studies on the development of larval E. multilocularis Leuckart, 1863, in the intermediate host. Jap. J. Vet. Res., 19 (suppl. 3) : 1-53.

Pedersen (A.), 1930. - Fortgesetzte Beiträge zur Kenntsis der Säugetier und Vogelfauna der Ostküste Grönlands. Med. om Gronl., 77: 341-507.

Pitelka (F. A.), Tомich (P. Q.) and Treichel (G. W.), 1955. - Ecological relations of jaegers and owls as lemming predators near Barrow, Alaska. Ecol. Monog., 25 : 85-117.

Preble (E. A.), 1923. - Mammals of the Pribilof Islands, pp. 102-120. In A Biologicai Survey of the Pribilof Islands, Alaska. E. A. Preble and W. L. McAtee Eds., USDA, Bureau of Biological Survey, Washington, No. Amer. Fauna No. 46.

Pruitr (W. O., Jr), 1957. - Observations on the bioclimate of some taiga mammals. Artic, $10: 130-138$.

RausCH (R.), 1952. - Studies on the helminth fauna of Alaska. XI. Helminth parasites of microtine rodents-taxonomic considerations. J. Parasit., 38: 415-444.

-, 1953 a. - On the land mammals of St. Lawrence Island, Alaska, Murrelet, 34 : 18-26.

- $1953 \mathrm{~b}$. - The taxonomic value and variability of certain structures in the cestode genus Echinococcus (Rud., 1801) and a review of recognized species, 233-246. In Thapar Commem. Vol., Dept. Zool., Univ. Lucknow, India.

- 1956. - Studies on the helminth fauna of Alaska. XXX. The occurrence of Echinococcus multilocularis Leuckart, 1863, on the mainland of Alaska. Amer. J. Trop. Med. Hyg., 5 : 1086-1092.

-, 1958 a. - Some observations on rabies in Alaska, with special reference to wild Canidae. J. Wildlife Mgt., 22 : 246-260.

-, 1958 b. - Echinococcus multilocularis infection. Proc. 6th Internat. Cong. Trop. Med. Malaria, 2: 597-610.

—, 1960. - Recent studies on hydatid disease in Alaska. Parasitologia, 2: 391-398.

-, 1963. - A review of the distribution of holarctic recent mammals, 29-43. In Pacific Basin Biogeography, J. L. Gressitt Ed., Bishop Museum, Honolulu.

—, 1967. - On the ecology and distribution of Echinococcus spp. (Cestoda : Taeniidae), and characteristics of their development in the intermediate host. Ann. Parasit. hum. comp., 42: 19-63.

-, 1972. - Observations on some natural-focal zoonoses in Alaska. Arch. Envir. Health, 25 : 246-252.

-, and Bernstein (J. J.), 1972. - Echinococcus vogeli sp. n. (Cestoda: Taeniidae) from the bush dog, Speothus venaticus (Lund). Zeit. f. Tropenmed. u. Parasit., 23: 25-34. 
-, and Nelson (G. S.), 1963. - A review of the genus Echinococcus Rudolphi, 1801. Ann. Trop. Med. Parasit., 57: 127-135.

-, and Richards (S. H.), 1971. - Observations on parasite-host relationships of Echinococcus multilocularis Leuckart, 1863, in North Dakota. Canad. J. Zool., 49: 13171330.

-, and Schiller (E. L.), 1951. - Hydatid disease (Echinococcosis) in Alaska and the importance of rodent intermediate hosts. Science, 113: 57-58.

- , - 1954. - Studies on the helminth fauna of Alaska. XXIV. Echinococcus sibiricensis n. sp., from St. Lawrence Island. J. Parasit., 40: 659-662.

- , - 1956. - Studies on the helminth fauna of Alaska. XXV. The ecology and public health signifiance of Echinococcus sibiricensis Rausch \& Schiller, 1954, on St. Lawrence Island. Parasitology, 46: 395-419.

-, and WiLson (J. F.), 1973. - Rearing of the adult Echinococcus multilocularis Leuckart, 1863, from sterile larvae from man. Amer. J. Trop. Med. Hyg., (In the Press.)

SCHILler (E. L.), $1954 a$. - Unusual walrus mortality on St. Lawrence Island, Alaska. J. Mammal., $35: 203-210$.

-, $1954 \mathrm{~b}$. - Studies on the helminth fauna of Alaska. XIX. An experimental study on blowfly (Phormia regina) transmission of hydatid disease. Exper. Parasit., 3 : 161-166.

-, 1955. - Studies on the helminth fauna of Alaska. XXVI. Some observations on the cold-resistance of eggs of Echinococcus sibiricensis Rausch and Schiller, 1954. J. Parasit., 41 : 578-582.

Sealy (S. G.), FAy (F. H.), Bédard (J.) and Udvardy (M. D. F.), 1971. - New records and zoogeographical notes on the birds of St. Lawrence Island, Bering Sea. Condor, $73: 322-336$.

Stephenson (R. O.), 1970. - A study of the summer food habits of the arctic fox on St. Lawrence Island, Alaska. Thesis, Univ. Alaska, Fairbanks.

TAST (J.), 1966. - The root vole, Microtus oeconomus (Pallaus), as an inhabitant of seasonally flooded land. Ann. Zool. Fennici, 3: 127-171.

Tномаs (L. J.), 1955. - Echinococcosis on St. Lawrence Island, Alaska. J. Parasit., 41 (no. 6, sec. 2) : 29 .

-, Babero (B. B.), Gallicchio (V.) and Lacey (R. J.), 1954. - Echinococcosis on St. Lawrence Island, Alaska. Science, 120: 1102-1103.

U.S. Weather Bureau, 1953. - Local Climatological Data, with Comparative Data, 1952, Gambell, Alaska. U.S. Dept. Commerce, Weather Bureau, Kansas City.

Virchow (R.), 1856. - Die multiloculäre, ulcerirende Echinokokkengeschwulst der Leber. Verhandl. phys.-med. Gesellsch. Würzburg, 6: 84-95.

Vogel (H.), 1955. - Úber den Entwicklungszyklus und die Artzugehörigkeit des europäischen Alveolarechinococcus. Deutsche Med. Wochenschr., 80: 931-932.

—, 1957. - Uber den Echinococcus multilocularis Süddeutschlands. I. Das Bandwurmstadium von Stämmen menschlicher und tierischer Herkunft. Zeit. f. Tropenmed. Parasit., 8: 404-456. (Transl. H. A. G. Nathan).

West (J. T.), Hillman (F. J.) and Rausch (R. L.), 1963. - Alveolar hydatid disease of the liver; rationale and technics of surgical treatment. Ann. Surgery, 157: 548-559.

Younc (S. B.), 1971. - The Vascular Flora of St. Lawrence Island with Special Reference to Floristic Zonation in the Arctic Regions. Harvard University, Cambridge, Contrib. Gray Herbarium No. 201. 